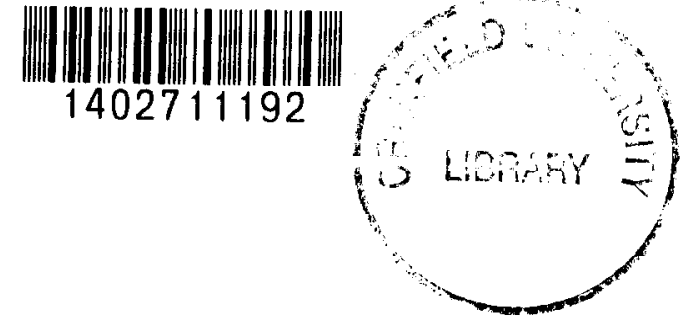

\title{
SWP 13/87 THE MANAGEMENT FACTOR IN ACQUISITION PERFORMANCE
}

\author{
PETER D HALL \\ Lecturer in Strategic Management \\ and \\ PROF DAVID NORBURN \\ Professor in Strategic Management \\ Cranfield School of Management \\ Cranfield Institute of Technology \\ Cranfield \\ Bedford MK43 OAL \\ United Kingdom
}

(Tel: 0234-751122)

(Fax: 0234 751806)

Submitted to Business Policy annd Planning Division:

1987 National Academy of Management Conference, New Orleans 


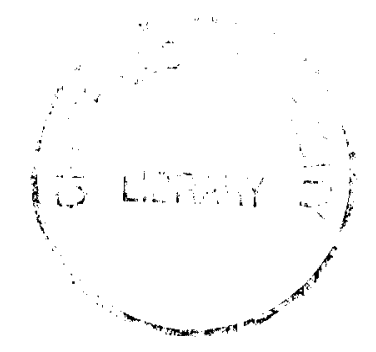

THE MANAGEMENT FACTOR

IN

ACQUISITION PERFORMANCE

PETER D. HALL

DAVID NORBURN

Lecturer in

Strategic Management

Professor in

strategic Management

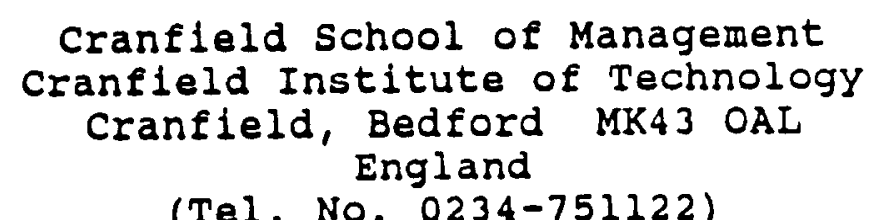

(Tel. No. 0234-751122)

Submitted to Business Policy and Planning Division: 1987 National Academy of Management Conference, New Orleans

(c) Hall Norburn, 1987 January 1987 


\section{ABSTRACT}

This paper reviews theoretical development and empirical investigation into the performance of Mergers and Acquisitions. In parallel it reviews recent research which links the performance of organlsations to the presence of an appropriate corporate culture. From these two theoretical platforms, the paper argues that the performance of acquisitions is determined by a match of culture and those organisational expectations which avoid post-acquisition managerial indigestion.

The paper finally proposes a programme of research to measure the performance of acquisitions against the criteria laid down by the acquiring management, and to determine the impact of culture clashes on those acquisitions perceived to have failed. 
In addressing the 1ssue of financial benefits from mergers and acquisitlons, overall research findings are consistent, and suggest that if shareholders' wealth maximisation is the primary objective, the impact for acquiring companies shareholders is at best neutral (Meeks 1977; Franks, Broyles \& Hecht 1977; Firth 1980). Despite this, contemporary statistics from the United kingdom show a continuing and widespread use of acquisition as a key element of corporate strategy, the average value of each having increased by nine times over the last decade (Business Monltor, 1984).

In parallel with the "Fourth wave" of acquisition activity (Hannah 1976) both conceptual and empirical momentum has linked corporate culture with organisation performance (Ansoff, 1979; Deal \& Kennedy, 1982; Harrison, 1972, 1978; Hofstede, 1980; Peters \& Waterman, 1982), Corporate culture beling collogulally defined as "the way we do things around here" (Bower, 1966).

Deal \& Kennedy's (1982) study of elghty companies found eighteen with clearly articulated qualitative beliefs ..."all were uniformly outstanding performers; we could find no correlation of any relevance amongst the other companies - some did O.K., some poorly, most had their ups and downs. We characterised the consistently high performers as strong culture companies".

Kitching (1967) 1dentifled variables such as the relative size of the companies, the market share position of the acquiree, the retention of acquiree management, and the post acquisition integration process, and related these variables to success as defined by the management of the acquiring company. Salter \& Weinhold (1979) similarly decided that successful acquisition outcomes were due to the 
"organisational structure and human resource skills of the acquirer coupled with latent synergistic possibilities".

These statements suggest that in unsuccessful acquisitions, either the expected benefits do not exist to meet the acquirers objectives or the release of the benefits is blocked in some way and the acquiring companies lack the management ability to achleve the release. The continuing popularity of acquisitions leads these authors to focus on this latter proposition.

The purpose of this paper is firstly to review the "state of the art" of scholarship concerning mergers and acquisitions by classifying according to methodological dimensions, and secondly, to suggest a programme of research to investigate the potential importance of management within the process, a subject of increasing emphasis within the corporate world.

Acquisition Performance:

The findings of the major studies concerning the impact of mergers on corporate performance which relate entirely to publically-quoted companies are summarised in Table 1 below, from which five general conclusions may be drawn:

1. Returns to the shareholders of acquiring firms are at best slight and tend to disappear rapidly, and, at worst, are significantly negative.

2. Returns to the shareholders of acquired firms are atrongly positive.

3. Gains and losses of victims and predators became a zero-sum. 
4. In certain cases a falled bid leads to improved stock market valuation.

5. Acquisitions were unlikely to reduce risk.

[Insert Table 1 about here]

Acquiring Companies:

The work of Firth (1976); Ellert, (1976); Elgers \& Clark (1980); Mlchel; Shaked \& Yobaccio (1983); and Dodds \& Quek, (1985); all found evidence of increases in share value and abnormal returns to the acquiring firm in the period leading up to the announcement of the merger bid. Ellert (1976) found that although share values showed an overall appreciation of 8.5 over the 24 months preacquisition, share performance declined in the last seven months prior to the merger. Conversely, following the announcement a reduction of this initial gain was generally observed. Firth $(1976,1980)$, and Barnes (1978, 1984), identified a sharp decline immediately following the acquisition event while Michel, shaked \& Yobaccio (1983), and Dodds \& Quek (1985), found a more gradual decline taking up to 55 months to eliminate the earlier gain.

Acquired Companies:

General agreement exists that the shareholders of the company to be acquired do considerably better out of the deal. Franks, Broyles \&echt (1977) found gains of 20 to the victim's shareholders in the three month period before an acquisition was announced. This led them to consider the possibility of "insider trading" leading to speculation in the victim's shares. Their work was confined to the Brewing Industry but was conflrmed by Wansley, Lane \& Yang (1983) in a study of 200 acquisitions where they identifed abnormal gains of 25 to the victims shareholders in the 40 days 
before the acquisition announcement. Using Cumulative Average Returns (CAR), Halpern (1973) Identifled positive abnormal gains of 30.48 and Malatesta (1982) showed gains of 22.28 within the last two months before the acquisition. All of these studies confirm that the shareholders of acquired firms earned abnormal gains from the merger, a conclusion embraced by the British press in contemporary commentary on the resignations of two major arbitrageurs.

Zero-sum:

However, Firth's (1980) study of 434 UK acquisltions concluded that no aggregate advantage accrued since the gains accruing to the victim were cancelled by the losses of the attacker. By adding the gains to the victims shareholders to the apparent long-term losses to the shareholders of the acquiring firms Franks, Broyles Hecht (1977) similarly conflrmed the Mandelker (1974) hypothesis of Perfectly Competitive Acquisition Markets which proposes that competition among acquiring firms will cause the value of expected benefits from merging to be paid to the shareholders of the firm being acquired.

\section{Bid Fallure:}

Firth's (1980) study found that unsuccessfui attackers outperformed the market in the twelve months following the falled bid, a result supported by Dodd \& Ruback (1977) who found that following the rejection of a bid, the target's shares falled to fall back to their preoffer level.

Risk:

Mason \& Goudzwaard (1976) Langetleg, Hangeu \& Wichern (1980); and Lubatkin \& O'Nell1 (1985); examined whether acquisitions were used to reduce the risk associated with a particular firm by managers. Lubatkin \& O'Nelll (1985) conclude that while certain types of acquisitions can reduce 
systematic (market related) risk they are not an effective means of reducing unsystematic (firm related) and total risk. Indeed Langetleg, Hangeu Wichern (1980) found that acquisitions tend to be associated with increased levels of systematic, unsystematic and total risk for the merged firms. Mason \& Goudzwaard (1976) concluded that Unit Trusts and portfolios of selected industry shares were a more effective way for shareholders to reduce their risk profile than the shares of conglomerate firms.

\section{MEASURING ACQUISITION PERFORMANCE}

Developed from the above, a major body of research has measured the financial performance of acquiring firms on the criterion that acquisition success would be reflected in short and medium term increases in shareholder wealth for which share price fluctuations compared with historic trends and industry norms have been used as constructs. Overall, by any traditional wealth or performance measure, acquisitions tend not to benefit the shareholders of the acquiring company in any way above the average. In aggregate there is no improvement in return, nor is there any decrease in risk which could not have been achieved by the individual investor.

This general result is unspectacular and might lead to the conclusion that acquisitions do not pay. However, further analysis is necessary before coming to a final conclusion. Bergman's (1983) comprehensive review of acquisition performance measures shows how the use of the Capital Asset Pricing Model (CAPM) and its variation Cumulative Average Residuals (CAR) as measures of acquisition performance have placed methodological constraints on researchers in several ways. 
- Examination of small samples has led to a need for a perfod of "clean" data around the merger event. The length of this period has ranged from 2 years either side of the event (Fama, 1976) to 5 years either side (Halpern 1973). In this context "clean" is taken to require the absence of any other acquisiton or major event which would distort the data. Yet Power (1983) and kitching (1967) have linked acquisiton success to the knowledge achieved through practise. Thus the need for clean data biases the sample by eliminating those companies with a higher probablilty of success through experience.

- The use of share price movements automatically limits the studies to publically quoted companies whlch by their nature are above average in size. Given that a sample chosen therefore is generally coupled with the need for the acquiree to be represented in a similar data base the net effect is that all studies have used as sample units those compantes which can only be described as extremely large.

- The small overall population of acquisitions has precluded attempts to group different types of acquisitions without coming up against statistical limitations and the "clean" data problem ldentified above.

Kitching (1974) looked at ways of using internal financial data e.g. return on investment, earnings growth and earnings per share before refecting them for the following reasons: 
- Destruction of numbers.

Because accounting systems are integrated and files are destroyed after the acquisition, it is normally impossible to get the necessary data after one or two years.

- Distortion of numbers.

Following an acquisition changes in accounting conventions, tax liabilities, transfer prices or head offlce charges, can lead to numbers changing their meaning

- Changes in operation.

After one or two years, operational changes can be so substantial that the company being measured no longer exists as a recognisible unit.

Kitching finally concluded "A good measurement technique must recognise that management motives for making acquisitions differ and that the weight accorded to each motive differs. Thus today's perception of success or failure must be a composite measure setting current satisfaction levels against the original motives".

Peters \& Austen (1985) 1dentify that "perception is all there 1s" and that only by understanding what the purchasers percelves to be success can we record actual achievement. Continuing the search for acquisition triggers, Boucher (1980) in a study for the Federal Trade commission identifled 31 possible motives for acquisition. The top 12 as 1dentified by respondents across two iterations of interviews are listed in Table 2 .

[Insert Table 2 about here] 
Therefore in measuring the success of an acquisition it is proposed that the constructs for performance should be the motives stated by the management of the acquiring company. Boucher's list of motlves will be used as a framework within the research programme for testing motives through the senior management team of the acquirer.

When Levinson (1970) looked at merger performance, he contended that "some psychological reasons for merger not only constitute a major, if unrecognised, force towards merger but they also constitute the basis for many, if not most, disappointments and fallures". He concluded that these hidden psychological reasons for acquisitions led to a condescending attitude towards the victim which results in efforts to manipulate and control. The use of Boucher's established framework will therefore be valuable in establishing true reasons for acquisition.

\section{CORPORATE CULTURE}

The relationship between corporate culture and organisation success has been ldentifled in recent years in both popular (Peters \& Waterman, 1982) and scholarly 11terature (Kilmann, Saxton, Serpa, 1986). Most have provided examples of strong organistional cultures and make prescriptive comment for running successful organisations. culture is becoming established as a relevant concept which is useful in understanding what makes organisations effective and unique.

Jay Lorsch defines culture as:

" ... the shared bellefs top managers in a company have about how they should manage themselves and other employees and how they should conduct their business" (Lorsch, 1986). He also made the telling 
point that "these beliefs are often invisible to the top managers but have a major impact on their thoughts and actions".

Other definitions include:

" a coherent system of assumptions and basic values which distinguish one group from another and orient its choices" (Gagliard1, 1986).

"the integrated pattern of human behaviour that includes thought, speech, action and artifacts and depends on man's capacity for learning and transmitting knowledge to succeeding generations" (Websters New Collegiate Dictionary).

"the way we do things around here" (Bower, 1966).

"a set of expected behaviours that are generally supported within the group" (Silverzweig \& Allen, 1976).

"shared philosophles, ldeologies, values, assumptions, bellefs, expectations, attitudes and norms that knit a community together" (Kilman, saxton \& Serpa, 1986).

Implicit in these definitions is the acceptance that while culture exists, it cannot be measured directly and the choice of approprlate constructs leads to variation of definition. As a result there is little, if any, empirical data that is clearly descriptive of existing organisation cultures. Culture remalns largely an anecdotal concept as it has been applied to the corporate environment, and there have been few attempts to develop a systematic, efficient measure of organisational culture. 
Two types of work have been conducted using culture as a predictor of success and may be categorised as:

- Culture and strategy

- Culture and performance

The first grouplng lncluding Lewin \& Minton (1986); Kets de Vries M Mller (1986); Lorsch (1986); and Reynierse and Harker (1986), use a combination of structured interview, questionnalres and longltudinal observations to determine a profile of organisational behaviour in a wide variety of situations. From an examination of the organisation's stated competitive strategy, a profile of required organisational behavlour can also be determined. Comparison of actual versus desired behaviour lead to a focussed programme of organisational change.

The second category includes the best sellers, Pascale \& Athos (1981); Ouch1 (1981); Peters \& Waterman (1982); in addition to that of Deal Kennedy (1982); and Reynolds (1986).

Peters Waterman identifled seven specteic beliefs which were consistently held and stated in their study of 62 "Excellent" organisations. Deal \& kennedy, over a period of 6 months, developed profiles of nearly 80 companies and found:

- only 25 had clearly articulated beliefs

- of these, two thirds (18 companies) had qualitative beliefs as opposed to financially oriented goals

- The 18 companies with qualitative beliefs were unfformly outstanding performers and were characterised as strong culture companies. 
Some of the high performers in Peters \& Waterman's study also appear in Deal \& Kennedy.

Norburn (1986) tested the characteristics of top managers within the U.K.'s largest companies against the performance of those industries in which they were strategically competing. He found significant differences in management characteristics between industry sectors categorised as growth, turbulent and declining. This work extends the upper-echelon theory of Hambrick \& Mason (1985) which posits that top mangement characteristics will, partially, predict organisational success. The significance of management style and corporate cultures within performance outcomes is therefore appropriate for further investigation

While emphasis has been placed on the existence of a strong culture in successful organsations, there is also recognised a need for an "appropriate" culture. Lorsch, (1986) describes culture as "the invisible barrier to strategic Change". Kilman, Saxton s Serpa (1986) subdivide the impact of culture on the organisation into:

- Direction

- Pervasiveness

- strength

If the culture is causing the organisation to behave in ways which are contrary to the expressed strategy then the impact of the culture is in the wrong direction. However, this might be less damaging if different cultures are perceived by different members of the organisation (not pervasive) or if the members of the organisation do not feel compelled to follow the dictates of the culture (weak culture). Thus the culture has a positive impact when it points behaviour in the right direction, is widely shared 
among members of the organisation and puts strong pressure on members to follow the established cultural guidelines. It will have a negative effect if it points in the wrong direction but may be neutralised elther by weakness or lack of general acceptance.

In the absence of outside influence the organisational culture 1 s relnforced and perpetuated in a "Virtuous Cycle" (Gagliard1, 1986) where the culture leads to cohesion and organisational efficiency which in turn, leads to the creation of a distinctive competence which creates economlc success which strengthens the values and beliefs.

However, when the problem solving alternatives offered by the culture prove unable to cope with changing environments, the virtuous cycle becomes a vicious cycle, which denies the obsolescence of the culture. Lack of success is then blamed on uncontrollable external forces or the behavour of specific groups or individuals in the organisation.

A simllar vicious Cycle can be ldentified where the culture is perceived to be successful, the organisation is perceived to be successful, yet change of culture is required by a major external upheaval such as the appointment of a new leader or the organisation's acquisition by another.

The change in culture caused by an acquisition may be real or perceived. In the case of perceived change the acquired company expects things to change and takes a defensive position unt11 it is proved that there will not actually be a change of culture. However, a real change may be seen as a "Revolution" which requires a complete 
rejection of existing values, or an "Evolution" which can be absorbed within the existing values and culture.

\section{HYPOTHESIS DEVELOPMENT}

The disappointing overall performance of acquisitions has led to a search for predictors of success, and the categorisation of acquisitions.

This categorisation starts at the planning stage opportunistic approach, research approach, combination approach (Fray, Gaylin \& Dawn, 1984), continues through the timig of the acquisition process - industry peaks and troughs (Beman, 1973; Bradley \& Korn, 1981; Kumar, 1977; Lynch, 1971; McCarthy, 1963; Salter \& Weinhold, 1979, 1982), and the method of payment-cash, stock or various combinations (Nielson, 1972; Allen, ollver \& Schwallie, 1981). However, the most generally used classification method is to compare the industry relatedness of the acquirer and the acquiree - the degree of "fit". Using this criterion, a summary of acquisition typology research is shown in Table 3 .

\section{[Insert Table 3 about here]}

Relatedness or degree of "fit" between acquirer and acquiree has been used in different stages of the research into acquisition performance.

The degree of industry relatedness was thought to explain acquisition success until the study of Cowling, stoneman, and cubbin (1979) demonstrated that the relationships held true only in high profit industries and not in low profit industries, thus linking both industry perfomance and acquisition performance. Kitching, (1967) identified a "fit" between company characterlstics (size, 
market share) in those acquisitions acknowledged as successful by the managers concerned.

The review of the impact of corporate culture on organisational performance suggests the existence of a further "fit" in successful acquisitons, that being the fit between organisational values and behavlours.

Although the significance of the managerial factor has been identifled, insufficient empirical investigation has been conducted relative to the importance of ensuring acquisition success. We therefore suggest four hypotheses as fruitful avenues for fleld research.

Hypothesis 1: Culture Match

The existence of strong cultures in outstandingly successful organisations has been demonstrated (Deal \& Kennedy, 1982) as has the mechanism to perpetuate and strengthen the culture even when faced with a need to change (Gagliardi, 1986). The need to change a culture as a result of an acquisition may be either perceived (if the cultures match) or Real (if a new culture is required). The time required to achieve Real cultural change may stretch to decades or generations (Lorsch, 1986), leaving the acquired organisation in a vicious cycle of resistance and poor performance.

H1. "The extent to which there exists a fit between the Culture of the acquiring organisation and the acquired organisation is directly correlated to the success of the acquisition".

Hypotheses 2 Autonomy

In Hayes, (1981) study of the reasons why executives stay with their company after it has been acquired, 758 of 
those who stayed enfoyed a satisfactory level of autonomy from their new parent. This is consistent with the concept of a percelved cultural change which allows the culture to settle back to its form after the initial uncertainty.

H2. Where a lack of fit in corporate culture exists, the success of the acquisition is determined by the amount of post-acquisition autonomy which is granted to the acquired organisation.

\section{Hypothesis 3: Pre-planning}

Jemison \& Sltkin (1986) state "The presence and use of ambiguity during the negotlating phase of an acquisition are often quite purposeful. But this same ambiguity when carried to the integration phase can be dysfunctional and reduce the chances for successful integration". Similarly, Hayes (1981) suggested that expectations of the future relationship are created during the negotiations. When these expectations are not met ex-post facto, executives become disillusioned, morale falls, performance declines and executives leave. This again is consistent with cox's (1981) identification of the fallure to link the negotiating team and the implementation team as a stumbling block to successful acquisition management.

Further Kitching, (1967) and Cox, (1981) suggested that many of the problems of style and expectations can be anticipated and that the creation of false expectations can be eliminated by adequate planning of the management issues and implications of the acquisition.

H3. The success of the acquisition is determined by the amount of pre-acquisition people planning that took place. 


\section{Hypothesis 4: Nerotiations}

Amongst the variables ldentifed by Kitching (1967) which related to the success of an acquisition were the retention of the acquiree management and the postacquisition integration process. He suggested that the management of the acquiring firm would increase the likelihood of success by matching the avallability of "managers of change" with the tasks of the newly merged enterprise and by specifying at the outset the control system to be used and then sticking to it.

However, in many acquisitions the tasks of analysing the potential of the target organisation and the way it will fit into the new structure is segmented because of 1 ts complexity. But this segmentation results in a lack of integration and a focus on strategic rather than organisational analysis (Jemison \& sitkin, 1986). Jemison \& sitkin also ldentify that the increasing momentum to close the deal can force premature closure and limit consideration of integration issues.

H4. In successful acquisitions a match in expectations exists in terms of personnel policy, remuneration. management style and degree of autonomy between the management teams of the acquiring company and the acquired company.

\section{CONCLUSIONS}

Theoretical and empirical research in strategic Management has developed from typologles of strategy through strategy formulation mechanisms and is now focussing on the managerial implementation issues of managing continuous change. In contrast, research on Mergers and Acquisitions has explored the structural issues of typology and performance and although several studies have commented on 
the 1mportance of management style, existing knowledge is iimited.

In seeking to develop a better insight into those aspects of research on Mergers which are in need of empirical development this paper, whilst recognising the difficulties of linking behavioural and performance issues, suggests directions for future research which would extend the 'static' models of mergers to include the changing aspects of organisational style and culture. 
suriery ve yefar seudlea on Benafles of mergers

\begin{tabular}{|c|c|c|c|c|}
\hline Auenor & Daen & $\begin{array}{l}\text { Yo. of } \\
\text { Conpanied } \\
\text { etuds }\end{array}$ & $\begin{array}{l}\text { neceuronene } \\
\text { gectode }\end{array}$ & PLAdLaqA \\
\hline pernese & 2978 & Is & $\begin{array}{l}\text { snare } \\
\text { price }\end{array}$ & 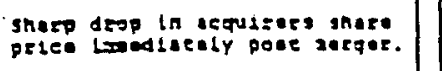 \\
\hline parmee & 2904 & Is is & snaz: & 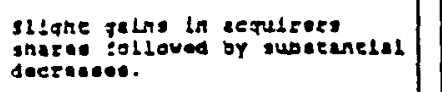 \\
\hline $\begin{array}{l}\text { Exot } \\
\text { phitlopecos }\end{array}$ & 1900 & 12 & narkes & 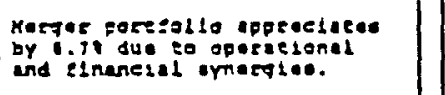 \\
\hline poat I kubeck & 1947 & $n / A$ & $\begin{array}{l}\text { snaes } \\
\text { pries }\end{array}$ & 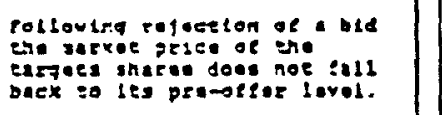 \\
\hline pods & 1900 & 191 & $\begin{array}{l}\text { Merkee end } \\
\text { ard }\end{array}$ & 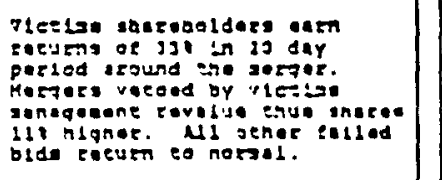 \\
\hline podds o ouek & 1903 & $n / \lambda$ & $\begin{array}{l}\text { Menthly } \\
\text { Cur }\end{array}$ & 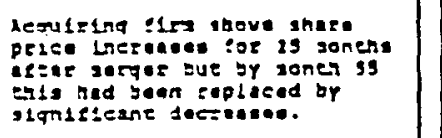 \\
\hline zlaters a clarx & 1900 & 337 & rezkes & 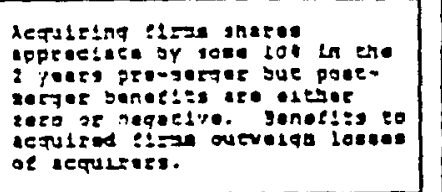 \\
\hline pilare & 1970 & 772 & Markere & 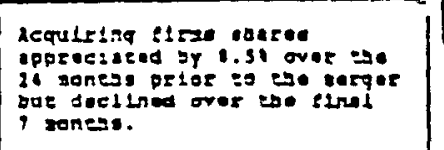 \\
\hline בتس1F & 1970 & $(\sigma x)$ & $\begin{array}{l}\text { sanes } \\
\text { peica }\end{array}$ & 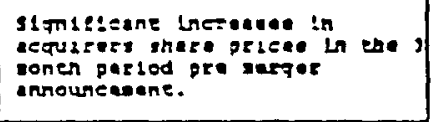 \\
\hline 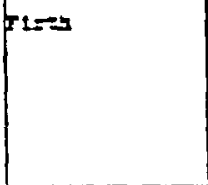 & 3980 & $(\sigma \pi)$ & $\begin{array}{l}\text { share } \\
\text { grieg }\end{array}$ & 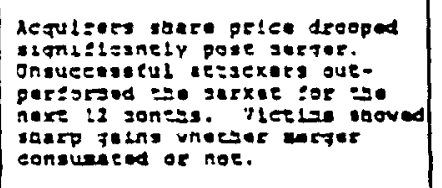 \\
\hline $\begin{array}{l}\text { Ezanks. } \\
\text { Bzoyber } \\
\text { gecie }\end{array}$ & 1977 & $\begin{array}{l}\text { (Jx) } \\
\text { oroving } \\
\text { Induets }\end{array}$ & an & 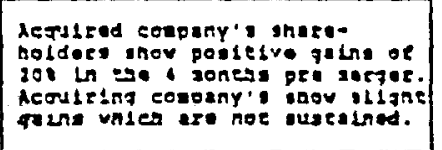 \\
\hline nelpern & | & 9 & $\begin{array}{l}\text { merxee } \\
\text { and cis', }\end{array}$ & 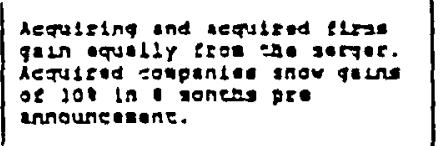 \\
\hline Rus ew ites & 1903 & $N / x$ & $\begin{array}{l}\text { Rod and } \\
\text { Marxat } \\
\text { roeusma. }\end{array}$ & 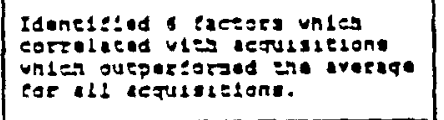 \\
\hline Lenget 109 & 1910 & 269 & nercee & 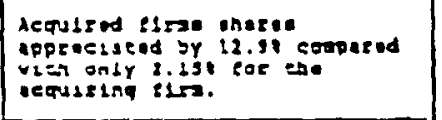 \\
\hline Lov: & 1972 & $N / \lambda$ & $\begin{array}{l}\text { smere } \\
\text { price }\end{array}$ & 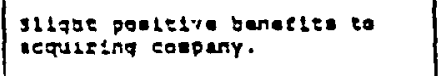 \\
\hline molatenes & 1418 & $x / x$ & ear'. & 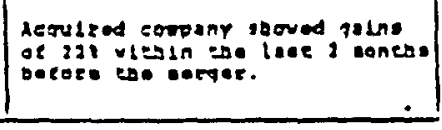 \\
\hline
\end{tabular}

\begin{tabular}{|c|c|c|c|c|}
\hline rundilxer & 2971 & 241 & Markoe & 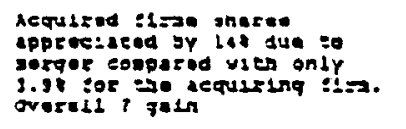 \\
\hline $\begin{array}{l}\text { Meoon ind } \\
\text { eoudzuesterd }\end{array}$ & 1974 & 22 & Aceounting & 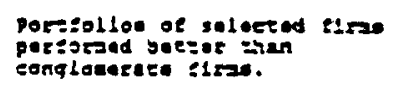 \\
\hline Nooke & 2911 & $\begin{array}{l}232 \\
(0 \times 1)\end{array}$ & 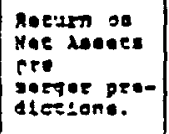 & 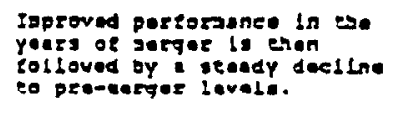 \\
\hline $\begin{array}{l}\text { rolsexor } \\
\text { r wiolson }\end{array}$ & 1871 & 116 & Necoune inq & 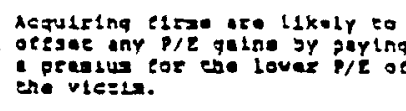 \\
\hline moltexer & 2973 & $n / \lambda$ & gnaze & 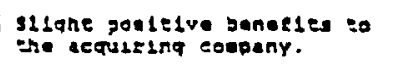 \\
\hline 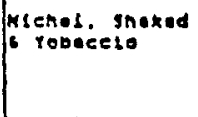 & 1901 & $n / A$ & en's & 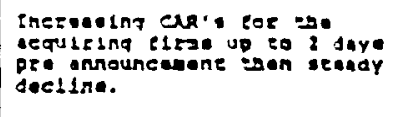 \\
\hline restseon & 1919 & $n / \lambda$ & $\begin{array}{l}\text { ess und } \\
\text { n.o.z. }\end{array}$ & 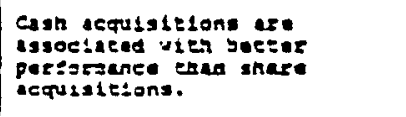 \\
\hline yersould & 1990 & $n / x$ & $\begin{array}{l}\text { Mare } \\
\text { intervisave }\end{array}$ & 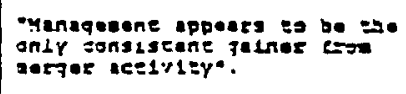 \\
\hline peasex I Jan & 1974 & 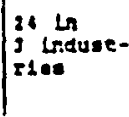 & $\begin{array}{l}\text { Mrnual } \\
\text { yezxoe } \\
\text { geeuste }\end{array}$ & 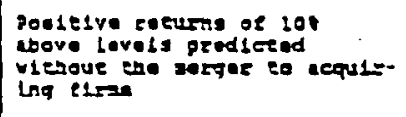 \\
\hline $\begin{array}{l}\text { Wonsiar, cand } \\
\text { c teage }\end{array}$ & 2809 & 800 & ouliy & 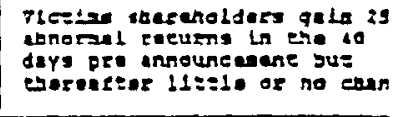 \\
\hline $\begin{array}{l}\text { Waseon : } \\
\text { Mansounqken }\end{array}$ & 2172 & 6 & Neeoureina & 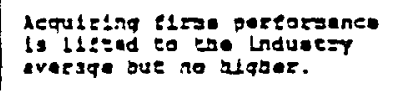 \\
\hline
\end{tabular}


TABLE 2

MOTIVES FOR ACQUISITION

MOTIVE

SCORE

RANK

Take advantage of awareness that a company is undervalued.

18.2

1

Achieve growth more rapidly than by

internal effort.

16.9

2

satisfy market demand for additional

product services.

$14 \cdot 5$

3

Avoid risks of internal start-ups

or expansion.

14.3

4

Increase earnings per share.

14.2

5

Reduce dependence on a single

product/service.

$13.5 \quad 6$

Acquire market share or position

11.6

7

offset seasonal or cyclical fluctuations

in the present business.

10.5

8

Enhance the power and prestige of the

owner, CEO, or management.

10.2

9

Increase utilisation of present

resources -- e-g- physical plant,

individual skilis, etc.

9.3

10

Acquire outstanding management

or technical personnel.

8.9

Open new markets for present

products/services.

$8 \cdot 5$

12

Source: W.I. Boucher F.T.C. Study June 1980 
Typology of Acquisitions

Related Acquisition

Guth 1980

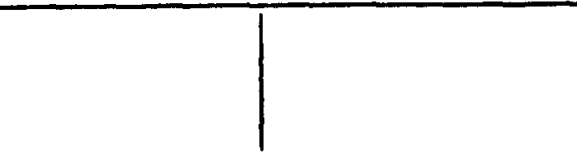

strategic

Guiniven 1985

Related Complimentary

Fekar 1985

Salter \& Weinhold 1979 Allen, Oliver \& Schwallie 1981 pekar 1985

Salter \& Weinhold

Allen oliver \&

schwallie 1981
Unrelated Acquisition

Guth 1980

Bettis \& Hall 1982

Montgomery 1979

Rumelt 1974

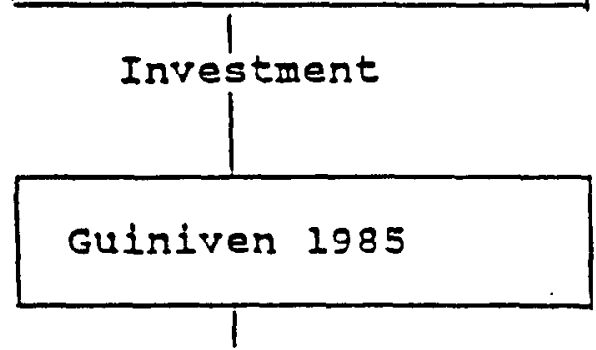

Pure Conglomerate/Conglomerate/ Selective Diversification

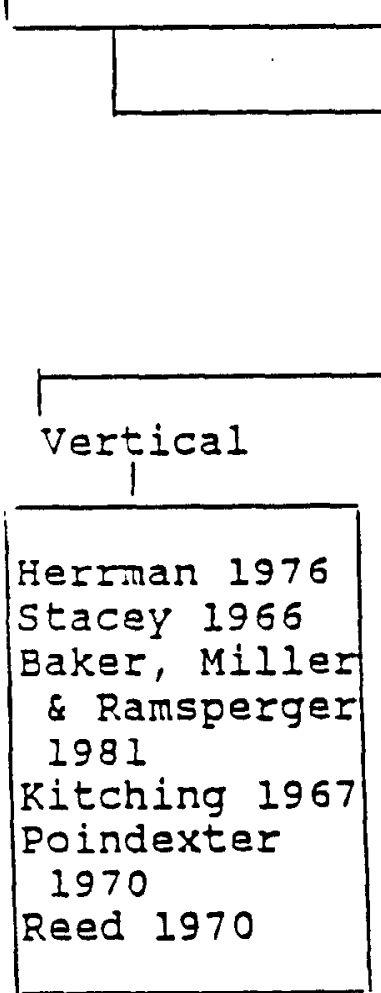

Related Supplementary

Baker, Miller \& Ramsperger 198 Poindexter 1970

Bradley \& Korn 1982

Wansley, Lane \& Yang 1983

Reed 1970

Pekar 1985

Salter \& Welnhold 1979

Allen, Ollver \& Schwallie 1981

Federal Trade Commission 1978
Horizontal

Chakrabart 1 \&

Burton 1983

Baker, Miller \&

Ramsperger 1981

Kitching 1967

Poindexter 1970

Reed 1970

Herrman 1976
Concentric Marketing Concentric Technology

Baker, Miller \&

Ramsperger 1981

Ritching 1967

Pothdexter 1970

Reed 1970

Herrman 1976
Chakrabarti \& Burton 1983

Baker, Miller \&

Ramsperger 1981

Kitching 1967

Poindexter 1970

Reed 1970

Herrman 1976 


\section{References}

Allen, M.G., Oliver, A.R. \& Schwallie, E.K. "The Key to Suceeseful Aequisitions". Joumal of Bucinees Straterx Vol.2 No.2, 1981 Ansoff, H. \& Weaton, F.J. "Merger Objectives \& Orcaniestion Strueture". Quarterly Review of Economics \& Businen, August, 1965 Ansoff, H. et al. Aequisition Behaviour of U.S. Manufacturine Firme 1946-85. Venderbill Univeraity Prean, 1971

Baker, H.K., Miller, T.O. \& Ramspercer, B.J. "An Inaide Look at Corporate Merger and Acquinitions". M.S.U. Businezu Topics Vol.29, Winter 1981

Barnes, J. "The Efrect of a Merger on the Share Price of the Attacker". Accounting and Buainese Research 1978

Barnes, J. "The Effect of a Merger on the Share Price of the Attacker Revisited". Accountingand Buriness Researeh, Winter 1984 Beman, L. "What We Learned from the Great Merger Frency". Fortune Vol.87, No.4. April, 1973

Bettis, R.A. \& Hall, W.K. "Divernifieation Stratecy, Accounting Dotermined Risk, and Accountint Determined Return". Aeademy of Management Journal Vol.25. No.2, June 1982

Birley, S. "Acquisition Stratery or Aequisition Anarchy" Joumal of General Manesement, Vol.3, No.3, Sprinc 1078

Boucher, W.I., "Merger Motiven" F.T.C. Study, 1980

Bradley, J.W. \& Kom, D.H. "The Changing Role of Acquisitione", Journal of Buninete Stratere Vol.2, No.4, 1982

Chakrabarti, A.K. \& Burton, J. "Technological Characteriatice of Mergere and Acquinitione in the 1070's in Manufacturing Industries in the U.S.". Quarterly Review of Economics and Buninew Vol.23, No.3, Autumn, 1983

Choi, D. \& Phillippaton, G.C. "Synerriem or Diverrifteation". Finaneial Manarement Aesoeiation Meetinx, 1980

Cowling, K., Stoneman P. \& Cubbin, J. "Merser and Economic Performance" Cambridre Unireraity Prece, 1979

Cox, C.A. "Marnhalling the Combined Resources". Handbook of Merren Acquititions and Buyoute (ode. S.J. Lee \& R.D. Colman) Prentice Hall, 1981

Deal \& Kennedy, A.A. "Corporate Cultures", Addien-Wesley, Readinc, Mase, 1982

Dodd, P. "Merger Proposals: Management Diecretion and Shareholder Wealth". Journal of Financial Economice, June 1980

Dodd, P.R., \& Ruback, R. "Tender Offers \& Stockholder Roturns: An Empirical Analyato". Journal of Financial Economica, Vol.5, No.3, 1977

Dodds, J.C. \& Quek, J.P. "Effect of Mercert on the Share Price Movement of the Aequiring Firm - \&.K. Study" Journal of Buainese Finance \& Accounting, Vol.12, No.2, Summar 1988

Drucker, P.F., Technolosy Manarement \& Society. New York, 1977

Elgars, P \& Clark, J. "Merger Types and Shareholder Returne - Additional Evidence". Finaneial Manszement, Summer 1980

Ellert, J.C. "Mergers, Anti-Trust, Law Enforcement \& Shareholden Returns". Journal of Finance, Vol.31, 1976

Firth, M. Share Prices and Mergers. Weatmead, Saxon House, 1978

Firth, M. "Takeovers, Shareholders Returns and the Theory of the Firm" Quarterly Journal of Economice, 1980

Franks, J., Broyles, J. \& Hecht, M. "An Induatry Study of the Profitability of Mercere in the UK" Journal of Finanee, Dee. 1977

Fray, L.L., Gaylin, D.H. \& Down, J.W. "Succesuful Acqutaition Planning". Journal of Buaineas Straters Vol.6 No.1, 1984

Gagliardi, P. "Th. Creation and Change of Organisational Culture: A Conceptual Framework" Organieation Studies $7 / 21986$

Guiniven, J.J. "Establiohine an ecquisition policy" European Manarement Journal Vol.3, No.2, 1986

Guth, W.D. "Corporate Growth Stratagies" Journal of Bueinese Stratercy Vol.1. No.2, 1980

Halpern, P. Empirical Estimates of the Amount and Distribution of Gaine to Companies in Mercer. Journal of Buninens, Vol.66, 1973

Hambrick, D.C. \& Maen P.A. "Upper-echelona: the Organieation a a Reflection of its Top Managers" Academy of Mansement Review Vol.9, No.2, April 1984

Hannah, L. "The Rise of the Corporate Economy" Methuen, London, 1976

Harrison, R. "Understanding your Organisations Charactez" Harvard Businese Review May/June 1972

Harvey, J. Manazement Guidee to Mersen and Acquiaitions. Wiley International, 1969

Hayes, R.H. \& Hoag, G.H. "Post Aequisition Retention of Top Management". Merrere and Aequinitione, Vol.9, Summer, 1974

Hayes, R.H. "What Happens to my People After I Sell" Handbook of Mergern Acquiaitions \& Buyouta, (eda.S.J. Leee \& R.D Colman) Prentice Hall, 1981

Herrman, A.L. "A Decision Model for Mergers and Aequisitions" Mergers and Acquigitione, Spring, 1976

Hofstede, G., "Cultures Consequences" Sage Publications, Beverley Hills, 1980

Jemison, D.B. \& Sitkin, S.B "Acquisitions: the Process can be a Problem" Harrard Butiness Review Vol.64 No.2, 1986

Kets de Vries M.F.R. \&e Miller, D. "Personality, Culture and Organisation" Aeademy of Manacement Review Vol.11 No.2. 1986

Kilman, R.H., Saxton M.J. \& Serpa, R. "Tenues in Undertandinc and Changing Culture" Cellfomis Manarement Review Vol.28. No.2 1986

Kitching, J. "Why Mergers Miscarty?" Harvard Business Review, Nov/Dec. 1967

Kumar, P. "Corporate Growth Through Aequisition" Managerial Planning, Vol.26, July/Auc. 1977

Kusewitt, J.B., "An Exploratory Study of Strategic Acquisition Factoro Rolatine to Performance" Strategic Management Journal, Vol.6, 1985

Langetieg, T.C., "An Application of a 3 Factor Performanee Index to Meaure Stockholder Gaina from Mergers", Journal of Financial Economics, Vol.6, 1978 
Levenison, H. "A Psychologit Discnoses Merser Fuilurs" Herverd Buninem Review, Mar/Apr, 1970

Lorach, 1.W. "Mapeping Culture: The Invisible Berrier to Strategic Chango" Califormia Manszement Review, Vol.28 No.2, 1986

Lynch, H.P. Financial Porformance of Conglomerates Harrard Bunineas Reviex, Mar/Apr, 1970

Mace, M.L. 4 Montgomery, G. Management Probleme of Corporato Acquisition. Harverd University Prese, 1963

Malateata, D.H. "The Wealth Effects of Morger Activity and the Objectiva Functions of Merging Firma" University of Wanhington,

Marcb 1982

Mandelker, G. "Risk and Return - The Caw of Merging Firm" Loumal of Financial Economica, Dec. 1974

Mavon, H.R. \& Gourswaerd, M.D. "Performance of Conglomerate Firma: A Portfolio Approach" Journal of Finance, Vol.21, 1976

McCarthy, G.D. "Acquivitione and Mercors" The Ronald Prea Co., 1963

Meeks, "Diseppointing Marriage: A Study of the Geine from Merger". Cembridge Univergity Prese, 1977

Melicker, R.W. \& Neiloon, J.F. "Financial Eactors thet Aftect Acquisition Prices". Review of Economic and Buainew Renearch. Vol.83, 1060

Melicker, R.W. \& Ruah, D.r. "The Performance of Conglomerate Firms: Recant Risk and Return Experience" Journal of Finance. May 1973

Michel, A. Shaked, I \& Yobaccio, B. "Evidence of Stockholder Retume from Altemative Merger Types". Bogton University, 1983

Montgomery, C.A. "The Menurement of Firm Divernification: Some New Empirical Evidence" Academx of Management Journal Vol.25. No.2, June 1982

Mueller, D.C. "The Effects of Conglomerate Mergers: A Survey of Empirical Evidence" Joumal of Bankingand Finance, Vol. Dec, 1977

Neileon, J.F. "An Analyais of the Infuence of Financial Profit Potentials on Premium Payments in Mergers Associated with Cast and Common Stock During the 1960'" RhD Dimertation Univenity of Colorade, 1972

Newbould, G.D. "Management and Merger Activity". Guthetead, 1970

Norburn, D. "Gogon, Yoyas \& Dodoe: Company Directors and Industry Performance" Strategic Management Joumal, Vol.7. No.2, 1986

Ouchi, W.G. "Thoory Z" Addison-Wealey, Resdint, Mes, 1081

Pacale, R.T., \& Athoe, A.G. "The Art of Japanew Management" Simon \& Schuater, Now York, 1981

Pekar, P. "A Strategic Approsch to Divorification" Jeurnal of Bunineas Stratery Vol.5 No.4, 1985

Peters, T.J. \& Waterman R.H. "In Search of Excellence" Harper \& Row, New York, 1982

Peters T.J. \& Aunten N. "The Pasion for Excellence" Harpar \& Row, Now York, 1985

Pickering, J. "The Implementation of Britiah Competition Poliey on Morgera" Europesn Competikion Law Review, Vol.1, 1980

Poindexter, E.O. "The Profitability of Induntrial Marger" PhD Theris Syracuse University, 1970

Power, D.J. Unpubliahed PhD Therit Unixenity of Winconin 1982

Reed, S.F. "Corporate Divernification" Mergen and Acquicitione Vol.6, No.4, July/Aug. 1970

Reynierse, J.H. \& Harker, J.B. "Masuring \& Managing Organiational Culture" Human Resource Planning Vol.9, No.1, 1986

Reynolds, P.D. "Organisation Cultura as Related to Induatry, Position and Porformance" Journal of Management Studies, May 1986 Rumelt, R.P. Divernity and Profitability Univeraity of Califomia 1077

Salter, M.S. \& Weinhold, W.A. "Divernification Through Acquisition: Strategies for Creating Economic Value". Free Press, 1979

Salter, M.S. \& Woinhold, W.A. "Chooning Compatible Acquisitione" Harvard Bunineas Review. Vol.69, Jan/Feb. 1981

Schick, R.J. \& Jen, F.C. "Merger Benefite to Shareholders of Acquired Firms" Financial Management, Winter, 1974

Sectoo, D.H.W. "The Stratecg of Large Horicontal Mergers - An Empirical Invertigation". Unpublished PhD Thesis Northwestern

Univenity, 1077

Silvergweig, S. \& Allon, R.F. "Changing the Corporat, Culture" Sloan Manarement Review, Spring, 1976

Stacey, N.A.H. Merren in Modern Bunines Hutchinson, 1886

U.S. Federal Trade Commievion "Statintical Report on Mergers and Acquinitione"

Wansley, J.W., Lane, W.R. \& Yang, H.C. "Abnormal Retume to Acquired Firme by Type of Acquisition and Method of Payment" Financial Manarement Vol.12, No.s, 1983

Weaton, J.F. \& Maneingka, S.K. "Teate of the Efriciency Performance of Conglomerate Firma" Journal of Finance Vol.26, 1971

White, J. "The Merger Wave - Is It a Problem?" Wall Street Journal, 11 Dec.1981 